研究課題評価

1.研究課題名:酸化還元活性金属錯体液晶における動的構造と物性制御

2.研究者氏名:張 浩徹

3.研究のねらい:

「物質の状態変換」は基礎学問領域における重要な研究対象であるばかりでなく、エネルギ一変換 や電子デバイス等、人類の社会生活においても必要不可欠である。本研究では、(1)如何に分子内に おける電子状態の多重度·自由度を増加させるか、また(2)如何にその状態が空間的に伝播しうる集合 系を創出するかという問いに対し「液晶」に着目した。数ある液晶の中でもディスク状分子が示すカラ ムナ一液晶相における分子配向の長距離的秩序は、ディスク状分子のコア間積層相互作用により構 築され、コアの電子構造が集合構造に反映される。本研究では、この様なコアに電子的柔軟性を付与 しうる「レドックス活性錯体」を導入し液晶場における動的変換を試みた。ジオキソレン錯体は電気化 学的及び化学的に誘起される「外圏電子移動 (Outer-sphere Electron Transfer (OET))によりベンゾキ ハン $\left(\mathrm{BQ}^{0}\right) /$ セミキノネート $\left(\mathrm{SQ} \mathrm{Q}^{-}\right) /$カテコラート $\left(\mathrm{Cat}^{2}{ }^{2}\right)$ 型を取りうる。更に、OET 能に加え金属一配位子軌道 のエネルギー的接近により、熱、光、圧カにより金属-配位子間に「内圏電子移動（Inner-sphere Electron Transfer (IET))」が誘起され ([low spin-Coll(SQ)(Cat)(L)] $\rightleftarrows\left[\right.$ high spin-CoI(SQ) $\left.\left.{ }_{2}(\mathrm{~L})\right]\right) 、$ スピン状 態、光吸収の変化を伴う双安定性を示し分子内電子構造に高い自由度を有する。本研究では、ジオキ ソレン錯体を基本骨格としたディスコチック型金属錯体液晶を形成し、液晶が示す構造柔軟性に加え、 構成分子モジュールの電子構造柔軟性を連動させた新規化合物群の創成を目的とした。IET 及び OET 能に基づいた柔軟な分子の電子状態と「固体、液晶、液体」という異なる構造的自由度、秩序を有 する集積構造が強くカップルした新しい物性·機能探索プラットホームを指向した。

4.研究成果:

4-1.分子内電子移動に同期した巨視的状態の可逆的変換

本研究では原子価互変異性平衡 (VT)移動に伴う巨視的状態の変換を誘起すべく、2 本の長鎖を分 子内に有する結晶性 VT 錯体、 [Co(Cnhpy)(3,5-DTBQ 2 ) (CoCntbpy; Cntbpy = 4,4' -dialkyl-2,2' -bipyridyl (3,5-DTBQ = 3,5-di- $t$-butylsemi quinonate or catecholate; $n=0,1,5,9,13)$ )合成した。磁化率の温度 依存性及び原子価間電荷移動吸収帯(IVCT)の加熱による消失からすべての錯体が $/ s-[\mathrm{Co}$ 耐 $\rightarrow$ $h s$-[Co"] 変化が観測されると同時に、DSC 曲線には同温度において吸熱 $(D H=11.7 \mathrm{kcal} / \mathrm{mol})$ が観測された。 XRD の温度依存性により、オリジナル結晶相(K1)がより長い長周期秩序を有する K2 相へと相転移す ることが明らかとなった。このような結晶一結晶相転移は CoC9bpy においても $417 \mathrm{~K}(D H=15.1$ $\mathrm{kcal} / \mathrm{mol})$ に観測されるが、鎖長の短い CoCObpy, CoC1bpy, CoC5bpy においては全〈観測されず一定 結晶相を保つ。以上の結果は、CoC9bpy 及び CoC13bpy においては長いアルキル長鎖の配向多様性 により、異なるパッキングへの変化が急激な部分的なVT 変換と同期的に引き起こされ、IET と結晶格 子の結合が初めて示された(Dalton Trans. 表紙に採用)。 
本研究では構造のさらなる柔軟化を指向し、分子内に 4 本の長鎖を有する、 $\left[\mathrm{Co}(\mathrm{C} n \mathrm{Opy})_{2}(3,6-\mathrm{DTBQ})_{2}\right]$ (CnOpy $=3,5$-dialkoxy- pyridine; 3,6-DTB $=3,6$-di- $t$-butylsemi quinonate or catecholate; $n=9,12,17$ ) (CoCnpy)を合成した。得られた紫色 $/ s-[\mathrm{Co}$ 盺結晶は $5-360 \mathrm{~K}$ の温度範囲で $S$ $=1 / 2$ に相当する温度に依存しない磁化率を示す一方、加熱により $380 \mathrm{~K}$ 付近で急激に $S=3 / 2$ $\left(h s^{-} \mathrm{Co}^{\mathbb{I}}\right)+1 / 2\left(\mathrm{SQ}^{-}\right) \times 2$ に相当する値に上昇する。またこの温度において IVCT 吸収帯は完全に消滅 する。これは IETによる $/ s-[\mathrm{Com}] \rightarrow h s-[\mathrm{Co}$ "I]への VT 移動とそれに伴う配位子電荷の均一化を示す。興 味深いことに、この温度においてすべての錯体の結晶性 XRD パターンは完全に消滅し、流動性を有 する緑色等方性液体への固液相転移が確認された。緑色 $h s-\left[\mathrm{Co} \mathrm{I}^{\mathbb{1}}\right]$ 液体相は、続く冷却過程にヒステリ シスを伴いながら球晶状に固化する。以上の結果は、1) 分子内というミクロな領域で生じる「一電子移 動」過程と、巨視的な状態変換の同期発現を示すとともに、2) 分子に帰属される物性に加え、状態の 差異に基づく異方性や秩序性等の双安定性の同期変換を示す。更に、3) 固液転移の性格を利用した 分子双安定性の速度論的制御を可能にし、これまでの分子双安定性系にはない新規な局面を有す る。

前述の同期性の機構に興味が持たれる。 $/ s-\left[\mathrm{Co}\right.$ 垧の結晶構造は、混合原子価配位子(SQ- $\left.\mathrm{Sat}^{2-}\right)$ を 有する極性 $/ s-[\mathrm{Co}$ 听が配列した二次元シ一ト構造及び相互貫通したアルコキシ鎖層の交互積層により 組み上がっている。これは、混合原子価配位子由来の極性 VT コアと非極性アルコキシ鎖の有効な相 分離を反映し、 $/ s-[\mathrm{Co}$ 町型が結晶相においてのみ存在しうることを示す。これは $/ s-[\mathrm{Co}$ 町ににおいては、 分子内に混合原子価状態に起因する電気双極子が存在するのに対し、hs-[Com]型においては存在し ないためである。即ち、スピンクロスオーバ一錯体と異なり、VT 変換に伴い分子内の極性が大きく変 化していることが結晶の安定性と同期性に強く起因している。この様なVT 変換を伴う同期的固液転移 の特異性は、Evans 法により測定したトルエン溶液中における磁化率変化からも示される。CoC12Opy の溶液内磁化率は緩やかな VT 平衡移動を示し、鎖長に依存しない VT 平衡を示す。溶液モデルによ る解析より $D H_{V T 1}=46.5 \mathrm{~kJ} \mathrm{~mol}^{-1}$ 及び $D S_{V T 1}=154 \mathrm{~J} \mathrm{~mol}^{-1} \mathrm{~K}^{-1}$ 、平衡温度 $\left(T_{c l}\right)=302 \mathrm{~K}$ が得られる。また 過冷却液体状態が示す温度依存性の同様の解析より、 $D H_{V T 2}=43.3 \mathrm{~kJ} \mathrm{~mol}^{-1}$ 及び $D S_{V T 2}=137 \mathrm{~J} \mathrm{~mol}^{-1}$ $\mathrm{K}^{-1}$ 、平衡温度 $\left(T_{c 2}\right)=316 \mathrm{~K}$ が得られる。重要なことは、この $T_{c}, T_{c 2}$ 共に同期変換が生じる $T_{\mathrm{m}}$ よりも低 温側であり、結晶状態においては $/ s-[\mathrm{Co}$ 町から $h s-[\mathrm{Co}$ 吥への VT 移動が抑制されていることを示す。ま $た D H_{m}-D H_{V T \text { tor } 2} D S_{m}-D S_{V T \text { tor } 2}$ より得られる VT 平衡の寄与を差し引いた $1 s-[\mathrm{Co}$ 叮結晶の仮想的融解 温度は、445(溶液) 及び $408 \mathrm{~K}$ (過冷却液体) と見積もられ、VT 発現により融点が降下していることを示 す。言わば、順(逆) 電子移動による結晶融解(結晶化)の「引き込み」を示す。即ち、全系(ミクロ分子 電子状態十マクロ相状態)は、互いが持つ熱力学的因子により独立に振る舞うのではなく、ミクロ分子 電子状態はマクロ相状態の安定性に引きずられつつ、マクロ相状態の不安定限界温度を引き下げ、 それと同期的に高温側の安定相へと変換される。これは、電子移動に伴いマクロ相を変換しうることを 明確に示すとともに、またその逆も真であることを示唆する。

\section{4-2. レドックス活性金属錯体液晶の創成と電気化学的レドックスの直接誘起}

本研究では、1)レドックス活性配位子 $\left.\left(\mathrm{R}-\mathrm{CatH}_{n}\right) 、 2\right)$ 金属イオン $(\mathrm{M}) 、$ 及び3) 含長鎖補助配位子(L)に 着目し 35 種の新規錯体群を合成した。得られた錯体はすべて、配位子上における酸化に基づき良好 な(多)電子ドナーとして働く、I 群に分類される錯体おいてはアルキル鎖の導入により、複数の錯体に おいて結晶一結晶相転移が観測され、集積構造の多様化が図られた。しかしより広い $\pi$ 平面を有する 
$\mathrm{HHT}$ 錯体においては、核数の増加に伴い積層構造の強化による溶解度と構造柔軟性の低下が明確 に現れた。一方、アルキル鎖数を増加した III 群において Cat 面は PdC nen 部位の立体障害により積層 構造の形成は見られず液晶相は発現しない。

液晶相発現のためには、中心剛直コアによる集積構造と部分融解状態にある長鎖部位の共存が条 件となる。I 群において欠如している部分融解状態、IIIIII 群において久如しているコアの積層構造は、 補助配位子に分岐鎖を導入した C8,10bpy を用いることで共存することが可能である。得られた新規液 晶錯体群, $[\mathrm{Pt}(\mathrm{R}-\mathrm{Cat})(\mathrm{C} 8,10 \mathrm{bpy})]\left(\mathrm{R}=\mathrm{Cat}^{2-}(31), \mathrm{Dhn}^{2-}\right.$ (32), $\mathrm{ClCat}^{2-}(33), \mathrm{MeCat}^{2-}(34), \mathrm{Es}^{2-}$ (35; 非液晶)) は室温において高粘度を有し、各透明点においてILへと転移後、冷却によりC6 対称性を有するデンド リックテクスチャを示す。XRD は低角領域に長距離秩序を示す鋭い回折と共に、20付近のハロ一が現 れ、その指数付けよりへキサゴナルカラムナ一相 $\left(\mathrm{Col}_{\mathrm{h}}\right)$ に属する室温液晶であることが明らかとなった。 カラム間距離及び分子サイズより、31-34 のカラム構造は、錯体 I 群において見られた交互に配向した 錯体分子の積層構造により組あげられる。これを反映するように、XRDに共通して $26^{\circ}$ 付近に面間隔約 $3.4 \AA$ の回折が現れ、平面コア部位の積層を示し、カラム内に秩序を有するへキサゴナルカラムナーオ 一ダ一相 $\left(\mathrm{Col}_{\mathrm{ho}}\right)$ を与える。1-6 の結晶構造との整合性より、最も極性の低い 32 において二量化は起き ない一方、極性の高い 35 においては二量化が促進される結果力ラムは形成されず非液晶となると理 解される。ことから分子内の双極子の設計により液晶相の安定性を制御しうることを示す。

前述の錯体液晶はI-III 群に酷似した電子ドナ一能を示すが、これらはさらに1) 室温液晶、2) $\mathrm{Co}_{\mathrm{ho}}$ 相 に由来する高い粘性、及び3) 非極性有機溶媒に可溶、4) $\mathrm{CH}_{3} \mathrm{CN}, \mathrm{DMSO}$,水に不溶という特徵を有する。 IET によるレドックス状態の変換並びにそれに伴うマクロ状態の変換を誘起するためには、「液晶状態 における直接的な電気化学特性」を測定する必要がある。上述の特徵は溶液中における電気化学特 性評価に加え、液晶相の直接的なレドックス応答の追跡を可能にした。溶液中においては、Cat の酸 化に由来する一対の酸化還元波が観測される。一方、 $\mathrm{CH}_{2} \mathrm{Cl}_{2}$ 溶液の ITO 電極上(WE)へとキャスティン グすることにより液晶性 $\left(\mathrm{Col}_{\mathrm{h}}\right)$ 薄膜得た。 $\mathrm{Col}_{\mathrm{h}}$ 相は WE に固定されているため、レドックス過程には電 解質由来の $\mathrm{ClO}_{4}^{-}$アニオンの固定相への出入りを伴う(eq. (1))。[Pt(Cat)(C8C10bpy)] $\left(\mathrm{Col}_{\mathrm{ho}}\right) \rightleftarrows$ $[\mathrm{Pt}(\mathrm{SQ})(\mathrm{C} 8 \mathrm{C} 10 \mathrm{bpy})]^{+} \mathrm{ClO}_{4}^{-}(\mathrm{X})+\mathrm{e}^{-}$eq. (1)

以上の結果は、サーモトロピック液晶相におけるレドックス変換を可能にすることを示した初の例で あり、レドックス過程により電子構造の変換や構造相転移、また対アニオン種の挿入による構造変形 や反応場としての利用も期待される。最後に、このような OET を有する金属錯体の物理的電荷注入の 可能性に興味が持たれるが、本研究ではレドックス活性錯体、NiI(o-diiminosemi quinonate) $)_{2}$ の薄膜形 成並びに $\mathrm{p}$ 型電界効果トランジスタ能の発現に世界に先駆け成功し、レドックス活性錯体への物理的 電荷注入と電荷輸送の実行性を示した。以上の結果からも得られた $\mathrm{Col}_{h \mathrm{O}}$ 相の電場、磁場、光照射に 加え電界効果型の相変換が期待される。

本研究では、柔軟構造を有する錯体集積体にレドックス活性コアを導入することで、ET とマクロ相が 絡む動的性質を模索し物質探索を行った。まず、IET 系において、IET と結晶融解の同期性を見いだせ たことは特筆するに值する。この結果は、分子内 IET とマクロ相の強い結合を示しており、外場印可に よるミクロ電子状態とマクロ相の直接的及び間接的変換を可能にすることを示す。更に、構造化学パラ メーターや外場パラメーターの制御により、ミクロ及びマクロ状態間の相互依存関係の強弱を制御する ことも期待され、非熱的な巨視的相転移や非熱的な分子物性変換を実現しうる。次に、配向制御を中 心に行われてきた液晶材料に対し、「電子系」を制御可能な液晶性物質群を提供できたことは大きな収 
穫である。液晶が本来示す構造柔軟性、外場応答性に加え、電子構造柔軟性を有する液晶群は、電 子系と構造の強い結合により、電子が活躍しうる新しい場を提供できると確信する。本研究により得ら れた液晶性錯体群が有するレドックス能を利用することで、OET 機構に基づいた分子トランジスタや太 陽電池等のエネルギ一材料、レドックス触媒やセンサ一等への応用が期待される。これは金属と配位 子の相互作用に立脚した IET, OET コアと構造柔軟部位の競演により達成できる物性であり、なぜ金属 錯体なのか?という問いに対しても一定の説得力を示せたと考えている。

\section{5.自己評価:}

本さきがけ研究において、レドックス活性金属錯体液晶の合成とその構造、物性の動的変換を目的 とし研究を進めてきた。液晶の安定化に予想以上の時間と労力を費やしたものの、内圏、外圏電子移 動能を有する40を超える新分子を創成することができた。その過程に、長鎖の導入による構造柔軟性 の付与により、「電子移動と同期した固液相転移」や、「レドックス活性金属錯体液晶」「液晶状態にお ける電気化学特性」という新物質、新物性、新機能を見いだすに至った。これまで溶液中及び固相にお いてのみ研究されてきたレドックス活性金属錯体に液体場、液晶場を与えうる分子を合成できた事は 今後の錯体化学分野のみならず、液晶科学、電気化学、分子エレクトロニクスやレオロジーの分野に 渡る幅広の研究対象を与えると確信する。今後は、IET 系における液晶相の発現及び磁場、電場、光 による「電子移動+マクロ相転移の非熱的変換」にチャレンジしたい。これにより分子メモリや多彩な 協同現象の発見が期待される。また本研究により得られたレドックス活性金属錯体液晶は空気中で安 定な室温液晶であり、液晶発現温度は $300^{\circ} \mathrm{Cを}$ 超える非常に優れた液晶特性を示す。今後は、レドック ス能という既知の液晶群に見られない電子構造柔軟性を基盤に、基礎的な電気化学的現象をはじめ、 電気化学応答と構造変換の連動性を利用したセンサー、メモリ、触媒等への応用展開を進める予定で ある。

\section{6.研究総括の見解:}

新規な特性を示す液晶の創製をめざして、レドックス活性金属錯体液晶を合成し、その構造や物性 の動的変化を明らかにしようとする研究であって、化学的に誘起される外圏電子移動能、あるいは熱. 光·圧力による金属一配位子間の内圏電子移動能を有する 40 を超える新分子を精力的な実験と考察 によって創出したことは注目される。とりわけ、液晶に構造柔軟性を付与するために導入した長鎖の 役割を含めて結晶一結晶相転移という現象について構造や安定性を速度論および熱力学をもとに解 明したことは高く評価できる。また、得られたレドックス活性金属錯体液晶は空気中で安定で、液晶発

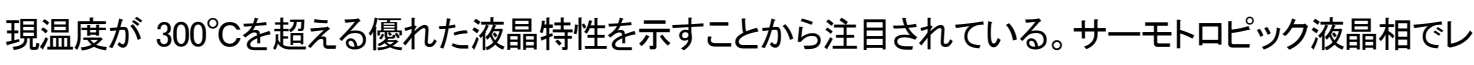
ドックス変換が起こるという新事実は、構造柔軟性と外場応答性を持つ液晶を電子の反応場として利 用できる可能性を示唆しており、液晶分野のみならず、電気化学、分子エレクトロニクスなどの分野に も影響を与えるものと期待される。

\section{7.主な論文等:}

論文

1. D. Kiriya, H.-C. Chang, A. Kamata, S. Kitagawa Dalton Trans. 2006, in press (Front Cover). 
2. S.-i. Noro, H.-C. Chang, T. Takenobu, Y. Murayama, T. Kanbara, T. Aoyama, T. Sassa, T. Wada, D. Tanaka, S. Kitagawa, Y. Iwasa, T. Akutagawa and T. Nakamura J. Am. Chem. Soc. 2005, 127, 10012-10013.

3. H.-C. Chang, N. Nishida, S. Kitagawa Chem. Lett. 2005, 402-403.

4. H.-C. Chang, D. Kiriya, and S. Kitagawa 2005, submitted for publication.

5. H.-C. Chang, T. Shiozaki, A. Kamata, T. Ohmori, T. Yamauchi, H. Furukawa, D. Kiriya, N. Nishi, S. Kitagawa 2005, submitted for publication.

6. H.-C. Chang, K. Mochizuki, S. Kitagawa Inorg, Chem. 2005, 44, 3810-3817.

7. H.-C. Chang, K. Mochizuki, S. Kitagawa Inorg, Chem. 2005, 44, 3799-3809.

8. K. Mochizuki, H.-C. Chang, T. Kawamura, S. Kitagawa Chem. Lett. 2005, 1622-1623.

9. S.-i. Noro, T. Sassa, T. Aoyama, H.-C. Chang, S. Kitagawa, T. Wada Proc. SPIE, 2004, 5517, 12-19.

10. 北川 進、張 浩徹、配位結合がつくる自己集合、自己組織化の世界、現代化学, 2003,

3 月号, 24.

\section{招待講演}

1. First International Symposium on Chemistry of Coordination Space, November 2005, Okazaki, Japan, "Redox-active Molecular Assembly within Solid, Liquid, and Liquid Crystal"

2. $5^{\text {th }}$ Japan-China Joint Symposium on Metal Cluster Compounds, August 2004, Okazaki, Japan,

"Structural and Physicochemical Controls of Ligand-unsupported Diruthenium Complexes with Catecholates"

3.「光エネルギーと物質変換 光合成·光触媒·太陽電池および関連化学の革新」、2004.11、金沢大 学、“レドックス活性金属錯体を用いた分子集団の動的制御と機能”

4.「錯体分子でなにができるか」、2004.3、分子科学研究所

“レドックス活性配位子を利用した機能性錯体集合体の構築” 